\title{
Biosorption and bioaccumulation of some heavy metals by deinococcus radiodurans isolated from soil in basra governorate - Iraq
}

\begin{abstract}
The bacterium Deinococcus radiodurans has been isolated from soil. On the basis of morphological, biochemical, 16S rRNA gene sequencing and phylogeny analysis revealed that, the isolates were authentically identified as D. radiodurans. D. radiodurans showed significant resistance to high concentrations of $\mathrm{Pb}$ and $\mathrm{Cd}$, but it was more tolerant to $\mathrm{Cd}$ than $\mathrm{Pb}$. Minimum inhibitory concentration was $400 \mathrm{mgl}-1$ for $\mathrm{Pb}$, while it was $600 \mathrm{mgl}-1$ for $\mathrm{Cd}$. The potent bacterium has the optimal bioaccumulation capacity differ according to metal type, concentration, and contact time. In bioaccumulation experiment, the results showed the highest increase in accumulation of $\mathrm{Pb}$ in the concentration $50 \mathrm{mgl}-1$ at $6 \mathrm{~h}$ of incubation (0.33 mgg-1), while the lowest accumulation was in concentration $5 \mathrm{mgl}-1(0.029 \mathrm{mgg} 1)$ at $2 \mathrm{~h}$ of incubation. For $\mathrm{Cd}$ the results showed maximum accumulation at $24 \mathrm{~h}$ for concentration $100 \mathrm{mgl}-1$ then decreased at $48 \mathrm{~h}$. The results of biosorption experiment showed that $\mathrm{D}$. radiodurans has a good ability to absorption both $\mathrm{Pb}$ and $\mathrm{Cd}$ in considering to the metals concentrations and times. This which can be clarified from the elevated percentage of $\mathrm{Pb}$ absorption (63.46\%) in concentration $50 \mathrm{mgl}-1$ and during $2 \mathrm{~h}$. For biosorption of $\mathrm{Cd}$ the was decreased with the increasing time and the high biosorption noticed during $2 \mathrm{~h}$ at concentration $50 \mathrm{mgl}-1(31.23 \%)$.
\end{abstract}

Keyword: Deinococcus radiodurans; Heavy metals; Minimum inhibitory concentration; Bioaccumulation; Biosorption 